\title{
THE COMPARATIVE ANALYSIS OF VILLAGE FINANCIAL MANAGEMENT
}

\author{
Maya Yusnita ${ }^{1 *}$ and Wenni Anggita ${ }^{2}$ \\ ${ }^{1,2}$ Universitas Bangka Belitung, Indonesia
}

\begin{abstract}
West Bangka was the only regency in Bangka Belitung Province that received a Fair Without Exception (WTP) in 2013-2014. Different with the East Belitung which has never received a WTP, even in 2014 East Belitung received Unqualified Opinion (TW). This study aims to analyze and compare village financial management and its level of suitability with The Minister Regulation Number 113 Year 2014. Qualitative analysis used to identify the constraints on village financial management, analysis of quantitative using Independent Sample $t$ Test. The object of this research are 26 villages in West Bangka and East Belitung. The results of this study showed that the obstacles of financial administration was caused by lack of understanding and guidance regarding the tasks, principal and functions of village apparatus. Reporting and financial accountability of the village is in accordance with the applicable rules, but there are 3 villages (11.54\%) that have not been in accordance with The Minister Regulation Number 113 Year 2014. The results of descriptive statistics, there are differences in reporting and accountability of village finance. However, there is no difference regarding administration of village revenues, expenditures and financing in West Bangka and East Belitung.
\end{abstract}

Keywords: Administration, Accountability, Village Financial Management

\section{INTRODUCTION}

According to the Law of the Republic of Indonesia Number 6 of 2014 about village, the village and the traditional village or called by other names, hereinafter called the village, is the unity of the legal community who have boundaries that are authorized to regulate and manage the affairs of government from local interests based on the initiative of the people, the rights of origin, or traditional rights recognized and respected by the Government administration system of the Republic of Indonesia (Astuti and Yulianto (2016), Widarnawati (2018)). Village is defined as a legal community unit with its teterritorial boundaries which has the authority to manage and organize the duties of the related local communities interests based on the origin and the related local customs within the district/city recognized and respected by the Governance System of the Republic of Indonesia (Kadir, 2017).

In Law number 6 year 2014 on the Village, provides government authority in the administration of village governance, implementation of development, community development and empowerment. Based on this rule, the central government disbursed funds for programs and activities from various sources from the State Budget (APBN) and the Province/District (APBD) in the Alocation of Village Funds (ADD) and Village Funds (DD).

The village funds was source from the State Budget (APBN) intended for villages that are transferred through the Regency/City of Regional Revenue and Expenditure Budget and used to finance the government administration, development implementation, community development, and community empowerment (Minister Regulation Number 113 Year 2014). Village financial management is the whole of activities which include planning, implementation, administration, reporting, and

* Corresponding author. Email address: mayayusnitaubb@gmail.com 
accountability of village finance. This rule also stated that administration was carried out by the village treasurer who was obliged to record every receipt and expenditure and close the book at the end of the month and report to the village head. The competency of the village head, including the village treasurer, were seen very weak. This was caused by the low level of education, so it was feared that in the management of village finances there will be errors and it is alleged that there was potential misstatement both administratively and substantively. The amount of funds to be managed by the village of village government has a fairly high risk in the management so that the competence of human resources is very necessary to manage finances of village well. Syaripudin (2014) showed that HR competencies did not influenced significantly on the quality of local government financial statements, this is different from Wati's study (2014), Rulyanti (2016), Karuniawan (2017), showed that the competence of human resources influenced significantly on the quality of the financial reporting of village (Widarnawati, 2018).

Research conducted by Barsap (2017) found that the quality of financial reporting villages influenced positively and significantly toward the good Governance (Amalya, 2017). Syahril (2013) proves that the administration of assets belonging to the region through SIMBADA carried out by the Asset Sector has not been reached optimally, there were still problems in the implementation. Sutri Kolinug et. al., (2015) shows that the management of fixed assets in the DPPKAD of Tomohon City with The Minister Regulation Number 17 Year 2007 not yet fully in accordance. Adi (2013) proves that the management and administration of village finance in Mulawarman Village is in accordance with the applicable laws and regulations. Syaril (2013) shows that Dr. H. Moh. Anwar Sumenep has not fully implemented the regulations stipulated by The Minister Regulation Number 61 Year 2007.

West Bangka Regency has succeeded in obtaining Unqualified Opinion (WTP) in 2013 and 2014. This achievement indicated that the financial statements have fairly presented and in accordance with Government Accounting Standards (SAP). West Bangka Regency Government is expected to provide examples and guidance on good financial management to the village government below. The villages are expected to be able to manage their finances which include planning, implementation, administration, reporting, and accountability properly and correctly so that transparent and accountable principles can be achieved. This condition is different from East Belitung Regency which has never received a WTP opinion. Even for the financial statements in 2014, East Belitung Regency was received Unqualified Opinion (TW), this was indicated that the financial statements didn't present a fair financial position. Many differences were also found in village funds utilization realization report between one village government with other village government in terms of accountability report content side (Fatmawati, 2018). The Government of East Belitung Regency was indicated unable to prepare its financial statements in accordance with SAP, so it was suspected that it could not be expected to provide examples and guidance to villages in the region which eventually villages could not properly manage their finances.

\section{LITERATURE REVIEW}

\section{Village Financial Management}

Village financial management is the whole activity which includes planning, implementation, administration, reporting, and village financial accountability. The Minister Regulation Number 113 Year 2014, regulates the principles of village financial management:

a) Transparent, the principle of openness that allows the public to know and get access to information as widely as possible about village finance.

b) Accountable, the realization of the obligation to account for the management and control of resources and the implementation of the policies entrusted in order to achieve the stated objectives. 
c) Participatory, the administration of village government that includes village institutions and elements of village communities;

d) Order and budget discipline, village financial management must refer to the rules or guidelines that underlie it.

The International Monetary Fund's (IMF) Country Poverty Reduction Report finds that village's financial management challenges have been regularly cited as a major harmful factor to substantial socio-economic development fulfillment in the villages (Kazimoto, 2013).

\section{Effectiveness of Village Funds}

According to Big Indonesian Dictionary, the word effective means the effect, effect, effect or can bring results. According to Bastian (2010) effectiveness is the level where the actual performance is proportional to the targeted performance. In terms of management of village funds, the effectiveness of the management of village funds is related to the implementation of all budget targets in accordance with the desired target and can be accountable on time (Azlina, 2017).

\section{Village Finance Administration}

Village Finance Administration is a recording activity specifically carried out by the Village Treasurer. The Village Treasurer must record all existing transactions in the form of receipts and expenses (BPKP, 2015). The Village Treasurer systematically and chronologically records financial transactions that occur. Village financial administration carried out by the Village Treasurer is done in a simple way, namely in the form of bookkeeping not yet using accounting journals. Administration of both cash receipts and disbursements using: General Cash Book; Tax Helper Cash Book; Bank account book.

The Village Treasurer records all receipts and expenses in the General Cash Book for cash. Whereas transactions of receipts and expenses through banks/transfers are recorded in the Bank Book. The Tax Assistant Cash Register is used by the Village Treasurer to record receipts of money originating from tax collection and record expenses in the form of tax payments to the State treasury. Specifically for opinions and financing, there is a subsidiary book in the form of Income Detail Book and Financing Details Book.

\section{Reporting and Accountability of Village Finance}

Accountability is an obligation to provide accountability and describes the performance and actions of someone possessing a legal entity within an organization to the party who has the right or authority to ask information or explanations regarding to the performed activities. The implementation of accountability in government agencies should consider the following principles: 1). Institution leader's and the entire staffs' commitment to manage the implementation of accountable missions; 2). system which ensures the utilization of resources consistent with the applicable legislations of law; 3). The demonstrated achievement level of the established goals and targets; 4). Orientation on the vision and mission achievements as well as the results and benefits. 5). Honesty, objectivity, transparency, and innovation as the catalyst for the managerial changes of the government agencies in the forms of method and performance measuring technique sophistication as well as the accountability report writing. Accountability is one of the forms in realizing good governance ((LAN \& BPKP (2000), Solikin (2006), Kadir (2017)).

Reports that must be prepared by the village in the context of reporting and accountability for village finance (BPKP, 2015) are as follows:

a) Report on Realization of Village Budget Implementation

The Rehabilitation Report of the village budget Implementation is submitted to the Regent/Mayor through the sub-district head, consisting of the First Semester Report, submitted no later than the end of July of the current year and the Year-End Semester Report, submitted no later than the end of January of the following year. 
b) Village Realization Realization Report

This report presents the realization of income, expenditure and financing from the village government compared to its budget in accordance with the changes of village income and expenditure budget for a particular fiscal year.

c) Report on Realization the Use of Village Funds

Report on Realization the use of village funds is submitted to the regent/mayor every semester. Submission of reports on the realization of village fund use is conducted for the first semester no later than the fourth week of July of the current budget year and for the second semester no later than the fourth week of January of the following fiscal year.

Based on the village funds report from the villages in the regency/city area, the Regent/Mayor submits the realization of distribution and consolidation of village funds to the Minister of Finance with copies of the village-handling minister, technical minister/head of the relevant non-ministerial government agency, and most governor later on the fourth week of March of the next fiscal year. Until this guide has been completed, there are no provisions that govern the Village Fund Report format that must be submitted by the village and the format of compilation that must be prepared by the district/city government.

d) Report on the Realization of the Implementation of the Village Income and Expenditure Budget

Report on the Realization of the Implementation of the Village Income and Expenditure Budget is a report submitted periodically to the BPD at the beginning of the year in the form of a Village Regulation.

e) Village Property Report

This report presents village property that basically represents the difference between assets owned by the village and the number of village obligations up to $31^{\text {th }}$ December of a year (IAI-KASP, 2015).

\section{RESEARCH METHODOLOGY}

\section{Sample}

The populations in this study are the village government officials in charge of financial management of villages in West Bangka and East Belitung regency. Sampling was done by technique purposive sampling with a technique of selecting samples based on specific criteria in order to obtain representative samples according to defined criteria (Cooper and Schindler, 2001 in Widarnawati, 2018).

Table 1 The Sample

\begin{tabular}{|c|c|c|c|}
\hline \multicolumn{2}{|c|}{ West Bangka } & \multicolumn{2}{|c|}{ East Belitung } \\
\hline District & Subdistrict & District & Subdistrict \\
\hline Parit Tiga & $\begin{array}{ll}\text { 1. } & \text { Air Gantang } \\
\text { 2. } & \text { Bakit } \\
\text { 3. } & \text { Cupat }\end{array}$ & Dendang & $\begin{array}{ll}\text { 1. } & \text { Balok } \\
\text { 2. } & \text { Dendang } \\
\text { 3. } & \text { Jangkang }\end{array}$ \\
\hline Kelapa & $\begin{array}{ll}\text { 1. } & \text { Air Bulin } \\
\text { 2. } & \text { Beruas } \\
\text { 3. } & \text { Dendang }\end{array}$ & Gantung & $\begin{array}{ll}\text { 1. } & \text { Gantung } \\
\text { 2. } & \text { Jangkar Asam } \\
\text { 3. } & \text { Lilangan }\end{array}$ \\
\hline $\begin{array}{l}\text { Simpang } \\
\text { Teritip }\end{array}$ & $\begin{array}{l}\text { 1. Air Nyatoh } \\
\text { 2. Berang } \\
\text { 3. Ibul }\end{array}$ & $\begin{array}{l}\text { Kelapa } \\
\text { Kampit }\end{array}$ & $\begin{array}{ll}\text { 1. } & \text { Senyubuk } \\
\text { 2. } & \text { Buding } \\
\text { 3. } & \text { Cendil }\end{array}$ \\
\hline Tempilang & $\begin{array}{ll}\text { 1. } & \text { Air Lintang } \\
\text { 2. } & \text { Benteng Kota } \\
\text { 3. } & \text { Buyan Kelumbi } \\
\text { 4. } & \text { Penyampak }\end{array}$ & Manggar & $\begin{array}{ll}\text { 1. } & \text { Kurnia Jaya } \\
\text { 2. } & \text { Lalang } \\
\text { 3. } & \text { Lalang Jaya } \\
\text { 4. } & \text { Baru }\end{array}$ \\
\hline
\end{tabular}

From Table 1 above, the sample of this study are Village Treasurer and Village Secretary from 26 villages in West Bangka and East Belitung. Respondents in this 
study amounted to 52 people consist of Village Treasurer and Village Secretary from each village.

\section{Data Collection and Analysis Techniques}

The data was collected by observation, documentation, literature study and interviews. This research method use mixed method that combines two forms of approaches in research, namely qualitative and quantitative (Creswell, 2010). Qualitative data analysis is used to answer the problem formulation regarding administration, reporting, and financial accountability in the villages of West Bangka and East Belitung. Quantitative analysis using Independent Sample t Test. In principle, the purpose of the two sample test is to find out the differences between two populations, by looking at the average of the samples.

\section{RESULTS}

Table 2 The Characteristics of Respondents

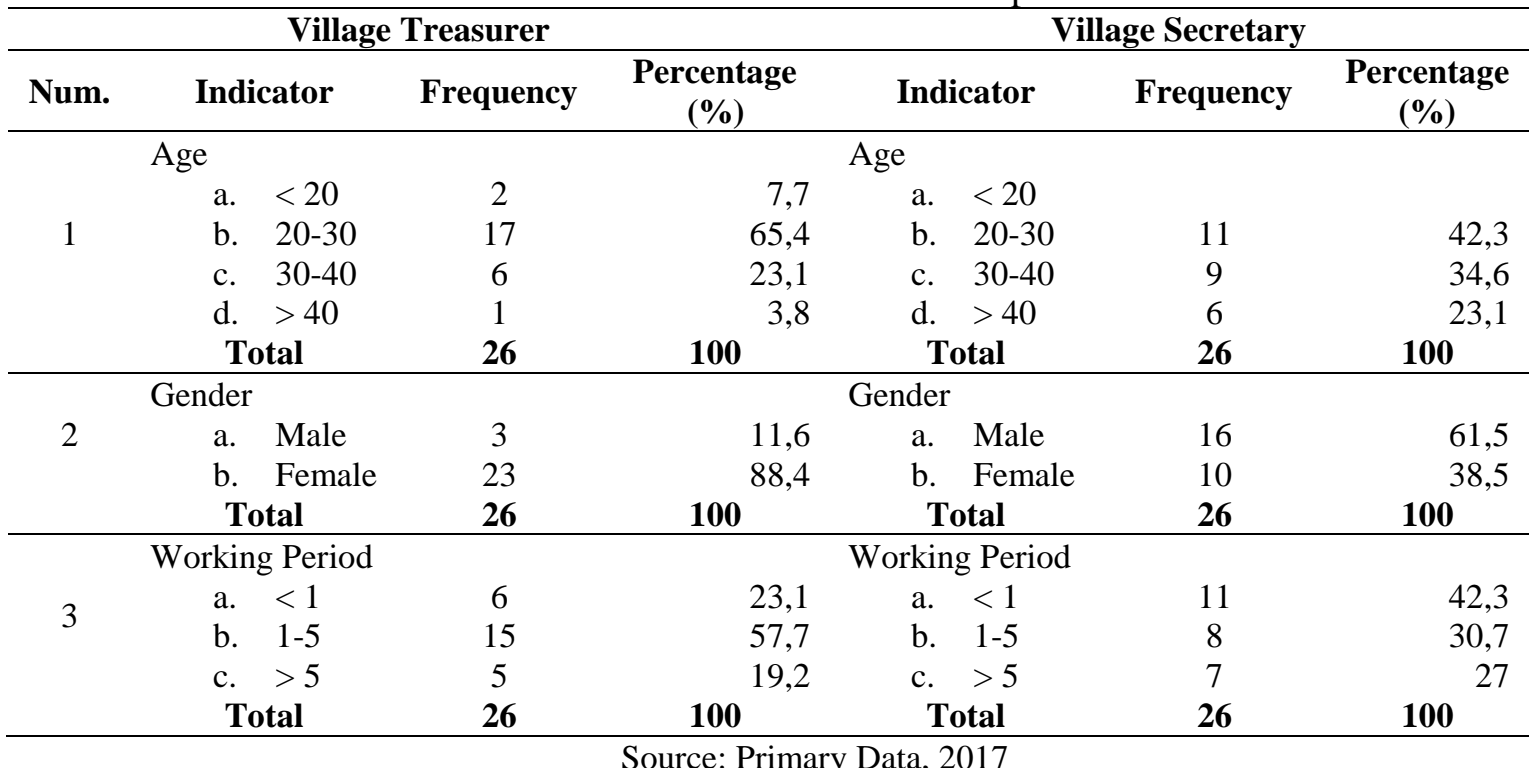

From Table 2 above, based on age characteristics, village treasurer is $30-40$ years old $(65.4 \%)$ with dominated by female $(88.45 \%)$. Grouping based on working period, on average the village treasurer has worked for $1-5$ years $(57.7 \%)$. The average age of village secretary is $20-30$ years old $(42.3 \%)$. Furthermore, based on gender, the village secretary on average is a male $(61.54 \%)$ with a working period mostly less than 1 year $(42.3 \%)$.

\section{A. Village Fund Administration Constraints}

Based on the results of the interviews with village secretary of West Bangka and East Belitung, constraints in village fund administration were found as follows: (a) Delay in disbursing village funds; (b) There was no guidance for managing village funds; (c) Lack of human resources; (d) The new village financial system; (e) Communication; (f) The unclear regulations; (g) Adjustment of the village's new system.

\section{B. Reporting Constraints and Accountability of Village Funds}

The information about the various obstacles which faced by the village treasurers is expected to be the subject of study and evaluation especially for the East Belitung Regency Government. The following are the obstacles experienced by the village treasurers: (a) Lack of understanding regarding PPH (Income Tax); (b) Delay in responsibility report; (c) Delay in Disbursement of Funds; (d) Lack of understanding of village apparatus about the application of village financial system; (e) Lack of guidance of village fund management; (f) Lack of understanding of reporting and 
AFEBI Management and Business Review (AMBR)

Vol.03 No.02, December 2018

accountability of the village funds; (g) Difficulty in dividing funds from detailed reporting.

C. Administration of Village Fund Revenues, Expenditures and Financing

Table 3 Paired Samples Statistics

Paired Samples Statistics

\begin{tabular}{|c|c|c|c|c|c|}
\hline & & Mean & $\mathrm{N}$ & $\begin{array}{c}\text { Std. } \\
\text { Deviation }\end{array}$ & $\begin{array}{c}\text { Std. } \\
\text { Error } \\
\text { Mean }\end{array}$ \\
\hline \multirow[t]{2}{*}{ Pair 1} & West Bangka & 1,6923 & 13 & ,63043 &, 17485 \\
\hline & East Belitung & 1,6923 & 13 & ,94733 & ,26274 \\
\hline
\end{tabular}

Based on the results of the descriptive statistics, there is no difference regarding the running process of administration of village revenue, expenditure and financing between village secretaries in West Bangka and East Belitung.

Table 4 Paired Samples Test

Paired Samples Test

\begin{tabular}{|c|c|c|c|c|c|c|c|c|c|}
\hline & & \multicolumn{5}{|c|}{ Paired Differences } & \multirow[b]{3}{*}{$\mathrm{T}$} & \multirow[b]{3}{*}{ df } & \multirow{3}{*}{$\begin{array}{l}\text { Sig. (2- } \\
\text { tailed) }\end{array}$} \\
\hline & & \multirow[b]{2}{*}{ Mean } & \multirow{2}{*}{$\begin{array}{c}\text { Std. } \\
\text { Deviation }\end{array}$} & \multirow{2}{*}{$\begin{array}{c}\text { Std. } \\
\text { Error } \\
\text { Mean }\end{array}$} & \multicolumn{2}{|c|}{$\begin{array}{l}95 \% \text { Confidence } \\
\text { Interval of the } \\
\text { Difference }\end{array}$} & & & \\
\hline & & & & & Lower & Upper & & & \\
\hline Pair 1 & $\begin{array}{l}\text { West } \\
\text { Bangka } \\
\text { - East } \\
\text { Belitung }\end{array}$ & 0,00000 & 1,41421 & ,39223 &,- 85460 &, 85460 & 0,000 & 12 & 1,000 \\
\hline
\end{tabular}

Based on the results of the analysis using SPSS, it can be concluded that $\mathrm{H}_{0}$ is accepted and $\mathrm{Ha}$ is rejected because the sig value $=1,000>0.005$. This means that there is no difference regarding the running process of administration of village revenue, expenditure and financing between village secretaries in West Bangka Regency and East Belitung Regency.

D. Reporting and Accountability of Village Finance

Table 5 Paired Samples Statistics

Paired Samples Statistics

\begin{tabular}{|c|c|c|c|c|c|}
\hline & & Mean & $\mathrm{N}$ & $\begin{array}{c}\text { Std. } \\
\text { Deviation }\end{array}$ & $\begin{array}{c}\text { Std. } \\
\text { Error } \\
\text { Mean }\end{array}$ \\
\hline \multirow[t]{2}{*}{ Pair 1} & $\begin{array}{l}\text { West } \\
\text { Bangka }\end{array}$ & 1,1538 & 13 & ,55470 &, 15385 \\
\hline & $\begin{array}{l}\text { East } \\
\text { Belitung }\end{array}$ & 1,2308 & 13 & 43853, & ,12163 \\
\hline
\end{tabular}

Based on the results of descriptive statistics, there are differences in reporting and village financial accountability between village treasurers in West Bangka and East Belitung. 
Table 6 Paired Samples Test

Paired Samples Test

\begin{tabular}{|c|c|c|c|c|c|c|c|c|c|}
\hline & & \multicolumn{5}{|c|}{ Paired Differences } & \multirow[b]{3}{*}{$\mathrm{T}$} & \multirow[b]{3}{*}{ df } & \multirow{3}{*}{$\begin{array}{l}\text { Sig. (2- } \\
\text { tailed) }\end{array}$} \\
\hline & & \multirow[b]{2}{*}{ Mean } & \multirow{2}{*}{$\begin{array}{c}\text { Std. } \\
\text { Deviation }\end{array}$} & \multirow{2}{*}{$\begin{array}{l}\text { Std. } \\
\text { Error } \\
\text { Mean }\end{array}$} & \multicolumn{2}{|c|}{$\begin{array}{l}\text { 95\% Confidence } \\
\text { Interval of the } \\
\text { Difference }\end{array}$} & & & \\
\hline & & & & & Lower & Upper & & & \\
\hline Pair 1 & $\begin{array}{l}\text { West Bangka } \\
\text { - East } \\
\text { Belitung }\end{array}$ &,- 07692 &, 75955 & ,21066 &,- 53592 & ,38207 &,- 365 & 12 & ,721 \\
\hline
\end{tabular}

Based on the results of the analysis using SPSS, it can be concluded that $\mathrm{H}_{0}$ is accepted and $\mathrm{Ha}$ is rejected because the sig value $=0.721>0.005$ means that there is no difference in reporting and village financial accountability between village treasurers in West Bangka and East Belitung.

\section{DISCUSSION}

a. Administration, Reporting and Accountability of Village Funds

From the results of interview with the Village Apparatus of West Bangka and East Belitung, the constraints in administration, reporting and accountability of village funds are mostly regarding the lack of understanding and guidance of the village secretary and treasurer regarding the duties, principles and functions charged. In addition, other administrative issues also become obstacles. This may be an input for the local district government to provide assistance, training and intensive development so that it is expected to increase the competencies possessed by village officials.

b. Administration of Revenues, Expenditures and Financing

This study showed that the administration of revenues, expenditures and financing in West Bangka and East Belitung in general has been running safely, smoothly and transparently. However, there were some villages that do not have a good village administration. The results of the study also obtained 21 villages (80.76\%) in accordance with The Minister Regulation Number 113 Year 2014. These results also showed that there were 5 villages (19.24\%) that were not suitable so that they were expected to be given special attention in administering village finances.

c. Reporting and Accountability of Village Finances

West Bangka and East Belitung as a whole are in accordance with applicable regulations. A total of 23 villages $(88.46 \%)$ were in accordance with The Minister Regulation Number 113 of 2014. There were 3 villages (11.54\%) which were not yet suitable, it was hoped that more attention could be given to the district government to socialize to local village officials.

\section{d. The Descriptive Statistics}

Based on the results of descriptive statistics, there is no difference regarding the running process of administration of village revenue, expenditure and financing between village secretaries in West Bangka and East Belitung. The sig value = $1,000>0.005$ means that there is no difference regarding the running process of administration of village revenue, expenditure and financing between village secretaries in West Bangka and East Belitung. Based on the results of descriptive statistics, there are differences in reporting and financial accountability of villages between village treasurers in West Bangka and East Belitung.

\section{CONCLUSION}

Based on the results of qualitative and quantitative analysis, it can be concluded that the constraints of administration, reporting, and accountability in West Bangka and 
East Belitung in general related to the understanding of village apparatus about the duties, principal, and function that were caused by the lack of assistance, training and development provided. Administration of revenues, expenditures and financing in West Bangka and East Belitung generally runs safe, smooth and transparent, but there were not all villages have followed The Minister Regulation Number 113 Year 2014. Based on the results of the descriptive statistics, there were differences in reporting and village financial accountability between village treasurers in West Bangka and East Belitung. However, there was no difference regarding the running process of administration of village revenues, expenditures and financing between village secretaries in West Bangka and East Belitung.

\section{References}

Adi, H. P. S. (2013). Implementasi Pengelolaan dan Penatausahaan Keuangan Desa Berdasarkan Perda No 16 Tahun 2007 Tentang Keuangan Desa Di Desa Mulawarman Kecamatan Tenggarong Seberang Kabupaten Kutai Kartanegara. E-Journal Ilmu Pemerintahan, 1(4).

Amalya, T. et al. (2017). Determinants of Village Financial Management and Its Implication toward Accountability: Study on Village Governance in West Lombok Regency. International Journal of Research in Advent Technology, 5(12). E-ISSN: 2321-9637.

Astuti, T. P., \& Yulianto. (2016). Good Governance Toward Rural Financial Management Applicability of Law No. 6 Year 2014. Periodic Journal of Accounting and Finance Indonesia, 1(1), 1-14.

Azlina, N. et al. (2017). The Effectiveness of Village Fund Management (Case Study at Villages in Coastal Areas in Riau). International Journal of Economic Research, 14(12). ISSN: 0972-9380,.

Barsap, R. S. M. (2017). The Rural Financial Reporting Quality: Testing Determinants and Its Implication toward Good Governance. [Post-graduate Thesis]. University of Mataram.

BPKP. (2015). Petunjuk Pelaksanaan Bimbingan \& Konsultasi Pengelolaan Keuangan Desa. Jakarta: Deputi Bidang Pengawasan Penyelenggaraan Keuangan Daerah.

Creswell, J. W. (2010). Research Design Pendekatan Kualitatif, Kuantitatif, dan Mixed. Yogyakarta: Pustaka Pelajar.

Fatmawati, A. et al. (2018). Village Funds Accountability and Misuse Prevention. Indonesian Journal of Business Finance and Accounting. ISSN 2598-6309, eISSN 2598-6295.

Government Regulation Number 60 Year 2014 on Village Funds.

IAI-KASP. (2015). Pedoman Asistensi Akuntansi Keuangan Desa. Jakarta: IAI.

Kadir, A. et al (2017). The Indonesian Perspecttives on Village Financial Management Accountability. International Journal of Economics, Business and Management Research, 1(4). ISSN: 2456-7760.

Kazimoto, P. (2013). Assessment of Villages Financial Management Challenges and Development Strategies in Tanzania, Arumeru District. International Journal of Research in Social Sciences, 3(2). ISSN 2307-227X. 
Karuniawan. (2017). Effect of Competence of Human Resources, Information Technology Application and Locus of Control on Financial Reports on Credit Institutions village in West Buleleng.

Lembaga Administrasi Negara dan Badan Pengawasan Keuangan dan Pembangunan. (2000). Akuntabilitas dan Good Governance, Modul 1 dari 5 Modul Sosialisasi Sistem Akuntabilitas Kinerja Instansi Pemerintah. Penerbit: Lembaga Administrasi Negara.

Rizqi, L. N., Domai, T., \& Wachid, A. (2013). Penatausahaan Asset Pemerintah Daerah melalui Sistem Informasi Manajemen Barang Daerah (Simbada) di Kabupaten Malang (Studi pada Bidang Asset Dinas Pendapatan Pengelolaan Keuangan dan Asset Kabupaten Malang). Jurnal Administrasi Publik (JAP), 1(1).

Rulyanti, D., (2016). Regulatory influence, Organizational Commitment, Communication and Human Resources Performance Against Village Government With Financial Management of village As an intervening variable (Studies in the village government in the regency). [Thesis]. Master of Management Faculty of Economics, University of Jember.

Santoso, S. (2011). Buku Latihan SPSS Statistik Parametrik. Jakarta: PT. Eleks Media Komputindo.

Solikin, A. (2006). Penggabungan Laporan Keuangan dan Laporan Kinerja Instansi Pemerintah: Perkembangan dan Permasalahan. JAP Vol. 2, No. 2. Departemen Keuangan.

Sugiyono. (2013). Metode Penelitian Pendidikan Pendekatan Kuantitatif, Kualitatif, dan $R \& D$. Bandung: ALFABETA.

Sutri, K. M., Ilat, V., \& Pinatik, S. (2015). Analisis Pengelolaan Aset Tetap pada Dinas Pendapatan Pengelolaan Keuangan dan Aset Daerah Kota Tomohon. Jurnal EMBA, 3(1).

Syahril. (2013). Pola Pengelolaan Keuangan Badan Layanan Umum Daerah (PPKBLUD) pada RSUD DR. H. Moh. Anwar Sumenep. Jurnal Performance Bisnis \& Akuntansi. Vol. 3. No.1.

Syarifudin, A. (2014). Influence of HR Competency and Role of Internal Audit on the Quality of Local Government Finance Report to the Government intervening variable Internal controlling System (empirical study in Kebumen regency). Business Focus Journal, 14(2).

The Government Regulation Number 6 Year 2014 on Village.

The Minister Regulation Number 113 Year 2014 on Village Financial Management.

Wati, D. K. et al. (2014). Effect of Competence HR, SAP Implementation, and Regional Financial Accounting System on the Quality of the Regional Financial Statements. E-journal Ak Ganesha Education University, 2(1).

Widarnawati, B. W. et al. (2018). Factors Affecting of Village Financial Management and Its Implication for Stakeholders Trust (Studi on Villages in Central Lombok, Indonesia). International Journal of Economics, Commerce and Management, 4(3). ISSN: 2348-0386. 